\title{
Effect of insecticide Alpha Super on phytopathogenic bacteria Pseudomonas syringae of agrophytocenosis of wheat
}

L. Butsenko, candidate of biological sciences

L. Pasichnyk, doctor of biological sciences

N. Buletsa,

V. Patyka, academician NAAS, doctor of biological sciences

Zabolotny Institute of Microbiology and Virology of NAS of Ukraine

The purpose. To study of effect of insecticide Alpha Super on morphological dissociation of phytopathogenic bacteria Pseudomonas syringae pv. Atrofaciens (McCulloch 1920) Young, Dye and Wilkie 1978, causal organisms of bacterioses of cereal crops. Methods. Classical microbiological and biochemical methods, ability to form a biofilm is studied at growth of $P$. Syringae pv. atrofaciens in polypropylene trays. Results. It is fixed that insecticide Alpha Super is characterized by negligible toxicity to phytopathogenic bacteria $P$. syringae pv. atrofaciens. It is shown that at action of the specimen Alpha Super amount of $\mathrm{R}$-forms of $P$. syringae pv. atrofaciens increases. Properties of the induced by insecticide Alpha Super R-forms of $P$. Syringae pv. atrofaciens UKM V-1011 are also studied. Conclusions. Insecticide Alpha Super causes morphological dissociation of phytopathogenic bacteria $P$. syringae pv. atrofaciens. R-forms of $P$. syringae pv. atrofaciens, induced by insecticide Alpha Super are characterized by greater resistance and form biofilms better, that increases surviving of these phytopathogenic bacteria in agrophytocenosis.

Key words: pesticides, insecticides, Alpha Super, P. syringae pv. atrofaciens, toxic action, R-forms, phytopathogenic bacteria.

Constantly in agrophytocenosis, phytopathogenic bacteria are exposed to all chemical substances that are used in significant amounts for intensive cultivation of agricultural plants [1]. However, when studying the impact of pesticides on biological objects, this group of microorganisms is almost completely out of the attention of researchers. However, our studies have found that fungicides and insecticides, without significant toxic effects on phytopathogenic bacteria of the species Pseudomonas syringae, may exhibit mutagenic effects on these bacteria. In addition, it has been established that some insecticides and herbicides can cause morphological dissociation in phytopathogenic bacteria [1].

Morphological dissociation of bacteria is one of the manifestations of the variability of microorganisms [2-4]. Due to the morphological dissociation of bacteria that form smooth brilliant colonies on dense media (usually they are referred to as S-forms), they begin to form mutated pleated matte colonies (roughforms, R-forms) [3]. Morphological dissociation in bacteria can occur spontaneously or under the influence of physical and chemical factors $[2,4]$. It should be noted that the morphological dissociation also changes the physiological, biochemical and immunological properties of bacteria. The phenomenon of dissociation promotes the heterogeneity of the bacterial population, increases its stability, expands the limits of survival of the species [2,5]. For phytopathogenic Pseudomonas syringae, the natural variability of the population with splitting into different morphotypes is characteristic, however, the frequency of such dissociation is small [4]. 
Of particular importance is the morphological dissociation for pathogenic microorganisms. It is known that in most cases it is accompanied by a change in virulent properties of bacteria. For the most part, the modification of colonies from smooth to rough type is accompanied by a decrease or even loss of virulence in pathogenic species, and for some pathogens, these phenomena are the opposite: R-form is virulent, S-form is weakly virulent [2, 3].

The purpose of the research is to study the effects of Alfa Super insecticide on morphological dissociation in phytopathogenic bacteria Pseudomonas syringae pv. atrofaciens (McCulloch 1920) Young, Dye \& Wilkie 1978.

Research methodology. The object of the research was the strains Pseudomonas syringae pv. atrofaciens (McCulloch 1920) Young, Dye \& Wilkie 1978 from the collection of live cultures of the phytopathogenic bacteria department of the Institute of Microbiology and Virology of the National Academy of Sciences of Ukraine: P. syringae pv. atrofaciens strain UKM B-1011 (PDDCC 4394), neopatotype strain; $P$. syringae pv. atrofaciens strain 9400 , isolated from the leaves of spring wheat of the Rannia 93 in the tillering phase (Kyiv region); $P$. syringae pv. atrofaciens 9417 , isolated from the leaves of spring wheat of the variety of Rannia 93 in the earing phase (Kyiv region).

The Alpha Super insecticide (Agricopter Asia Limited, Hong Kong, People's Republic of China) with active substance alpha-cypermethrin, $100 \mathrm{~g} / \mathrm{I}$ (chemical grade synthetic pyrethroids, grade II, weakly toxic substances) was studied. Alpha Super is an insecticide of contact action used to protect crops such as winter wheat, barley, alfalfa, peas, cabbage, apple, plum, sugar beet. Actively used against sunn pest (Eurygaster integriceps Put.), wheat thrips, leeches, aphids, pea weevil, tryps, scoops, moths, etc. [6].

The cultivation of bacteria was carried out on potato broth and potato agar at a temperature of $28^{\circ} \mathrm{C}$. Morphological, culturial and physiological and biochemical properties of bacteria were determined according to the described methods [7].

To detect the ability to form a biofilm, the bacteria were cultivated in polypropylene planshets, adding 2 $\mathrm{ml}$ of potato broth into the wells [7].

The response to supersensitivity, serological properties, the ability to survive at different temperatures and at different salt concentrations was determined according to the methodological recommendations [9].

Statistical processing of the results was carried out using the package STATISTICA v.6.0.

Research results. At the current level of development of agriculture it is impossible to completely abandon the use of pesticides (insecticides). However, when assessing the possibility of widespread use of pesticides it is necessary to take into account their influence on non-target organisms with which these substances are contacted in agrophytocenoses.

It has been established that insecticide Alpha Super has no antibacterial activity against phytopathogenic bacteria Pseudomonas syringae pv. atrofaciens. However, after inoculation of phytopathogenic bacteria $P$. syringae pv. atrofaciens with insecticide Alpha Super observed growth on agar medium of colonies of two types: typical S-forms (smooth, shiny, with raised center and smooth or slightly wavy edges) and modified Rforms colonies (rough, matte, flattened and larger, with uneven edges) (Fig. 1).
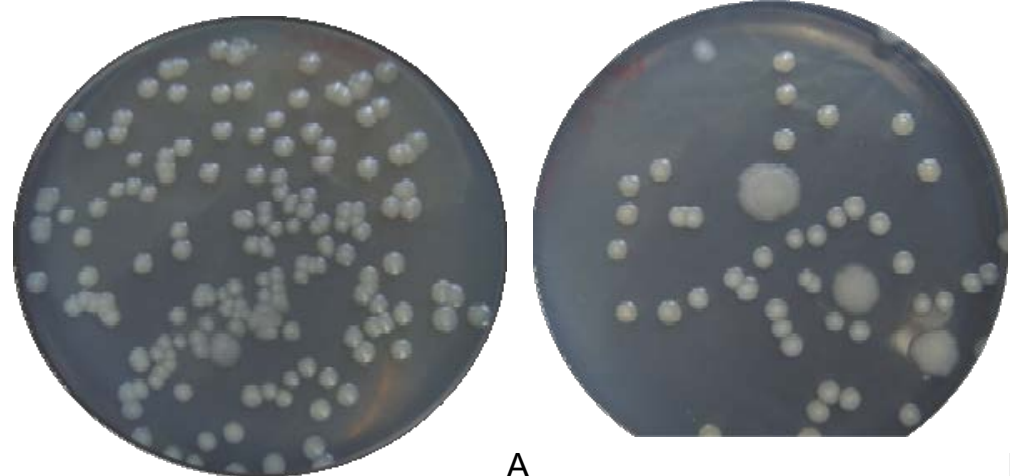

A

Б

Fig. 1. Colonies of $P$. syringae pv. атрофрациенс on potato agar: $A$ - the initial strain of $P$. syringae $p v$. atrofaciens UKM B-1011; B - S- and R-forms of $P$. syringae pv. atrofacients UKM B-1011 after action of insecticide Alpha Super 
For phytopathogenic bacteria $P$. syringae, the phenomenon of spontaneous morphological dissociation is known for a long time [4], but the frequency of such dissociation does not exceed $10^{-3}$. After processing of cells $P$. syringae pv. atrofaciens of Alpha Super insecticide we observed a significant increase in the frequency of morphological dissociation in 10 to 100 times. The frequency of occurrence of R-forms depended from $P$. syringae pv. atrofaciens strain. So, for $P$. syringae pv. atrofaciens UKM B1011 the frequency of appearance of R-forms was $5 \times 10^{-2}$, for $P$. syringae $\mathrm{pv}$. atrofaciens $9400-2 \times 10^{-}$ 2. P. syringae pv. atrofaciens 9417 strain was the most susceptible to the insecticide studied - the incidence of R-forms was $2 \times 10^{-1}$ (Table 1). In addition, the emergence of R-forms induced by insecticide was observed already at the initial and early stationary stages of bacterial cultivation, while spontaneous R-forms appeared in the late-stationary and phase of dying.

1. Morphological and cultural dissociation Pseudomonas syringae pv. atrofaciens under the action of alfa super insecticide

\begin{tabular}{|l|l|l|l|l|l|l|}
\hline \multirow{2}{*}{ Test } & \multicolumn{2}{|l|}{$\begin{array}{l}\boldsymbol{P} \text { syringae pv. } \\
\text { atrofaciens UKM B- } \\
1011\end{array}$} & $\begin{array}{l}\boldsymbol{P} \text { syringae pv. } \\
\text { atrofaciens } 9400\end{array}$ & $\begin{array}{l}\text { P. syringae pv. } \\
\text { atrofaciens } 9417\end{array}$ \\
\cline { 2 - 7 } & alfa super & con-trol & $\begin{array}{l}\text { alfa } \\
\text { super }\end{array}$ & con-trol & $\begin{array}{l}\text { alfa } \\
\text { super }\end{array}$ & control \\
\hline $\begin{array}{l}\text { Frequency of occurrence of } \\
\text { R-forms }\end{array}$ & $5 \times 10^{-2}$ & $5 \times 10^{-3}$ & $2 \times 10^{-2}$ & $1 \times 10^{-3}$ & $2 \times 10^{-1}$ & $5 \times 10^{-3}$ \\
\hline $\begin{array}{l}\text { Time of R-forms occurrence } \\
\text { (hours of cultivation) }\end{array}$ & 8 & 24 & 24 & 48 & 24 & 48 \\
\hline
\end{tabular}

Morphological dissociation results not only in the change in the appearance of bacterial colonies, but also in the alteration of their physiological and biochemical properties. It may affect on their ability to survive in the environment, colonize different surfaces, change virulent properties [3, 5, 9].

Virulent properties of phytopathogenic pseudomonas correlate with their ability to induce the hypersensitive reaction $(H R)$ in tobacco leaves.

Therefore, to verify the preservation of virulent properties in the investigated R-forms $P$. syringae pv. atrofaciens tested their ability to induce HR. It has been established that $P$. syringae pv. atrofaciens UKM B-1011 from modified R-colonies caused an hypersensitive reaction on the leaves of Nicotiana tabacum, as well as the typical S-morphotype (Fig. 2). According to literature, spontaneous morphological
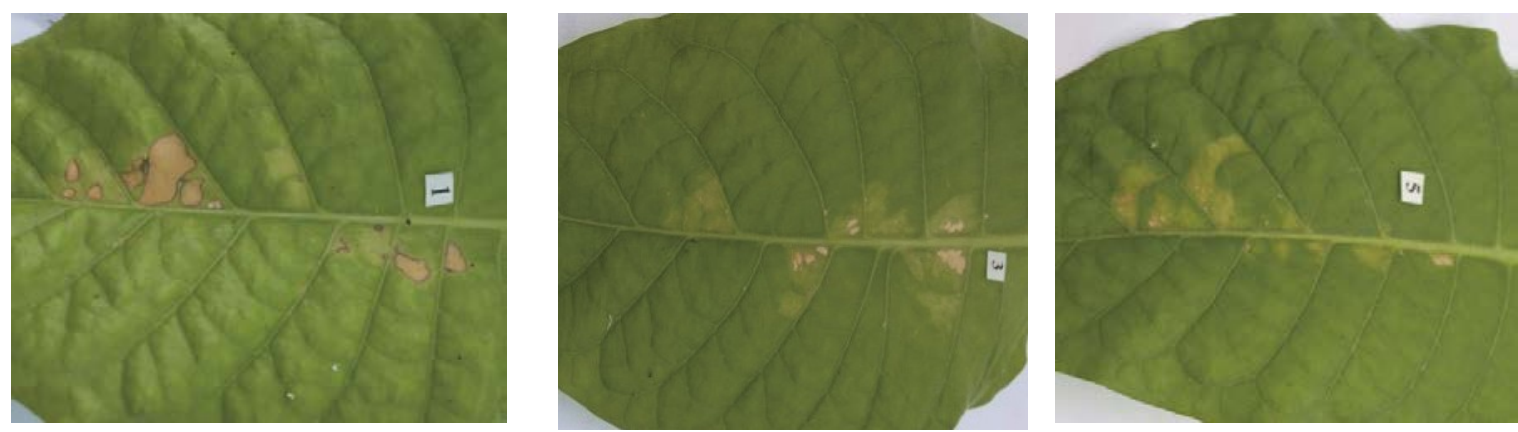

dissociation of $P$. syringae also does not affect their virulence [4].

a

$\mathrm{b}$

C

Fig. 2. Hypersensitive reaction caused by P. syringae pv. atrofaciens UKM B-1011 (a), its spontaneous (b) and induced by a pesticide Alpha Super (c) dissociants

In order to study the ability of R-forms $P$. syringae pv. atrofaciens to survive in the environment we examined their ability to grow at high and low temperatures and high concentrations of sodium chloride. It has been established that R-forms of $P$. syringae pv. atrofaciens UKM B-1011 (spontaneous and 
induced) better than the initial S-form grow at a temperature of $40^{\circ} \mathrm{C}$. Concentration of R-forms cells $P$. syringae pv. atrofaciens UKM B-1011 after 48 hours of cultivation were 10 times higher than S-forms (Table 2). There was no significant difference in the ability of $\mathrm{S}$ - and R-forms of $P$. syringae pv. atrofaciens UKM B-1011 grow at a temperature of $6^{\circ} \mathrm{C}$ and at concentration of $4 \% \mathrm{NaCl}$ (табл.2).

\section{Growth of $P$. syringae pv. atrofaciens UKM B-1011 S- and R-forms under different cultivation} conditions

\begin{tabular}{|l|l|l|l|}
\hline Growth conditions & \multicolumn{3}{|l|}{$\begin{array}{l}\text { Concentration of } P \text {. syringae pv. atrofaciens UKM B-1011 cells after 48 } \\
\text { hour cultivation, CFU/ml }\end{array}$} \\
\cline { 2 - 4 } & S-form & $\begin{array}{l}\text { Spontaneous R- } \\
\text { form }\end{array}$ & Індукована інсектицидом R- form \\
\hline $\begin{array}{l}\text { Growth at a temperature of } \\
40^{\circ} \mathrm{C}\end{array}$ & $3 \times 10^{5}$ & $27^{\star} 10^{5}$ & $25 \times 10^{5}$ \\
\hline $\begin{array}{l}\text { Growth at a temperature of } \\
6^{\circ} \mathrm{C}\end{array}$ & $13 \times 10^{7}$ & $11 \times 10^{7}$ & $12 \times 10^{7}$ \\
\hline Growth at $\mathrm{NaCl} 4 \%$ & $15 \times 10^{6}$ & $11 \times 10^{6}$ & $28 \times 10^{6}$ \\
\hline
\end{tabular}

Successful colonization of the surface of the plant is a prerequisite for the survival of phytopathogenic bacteria and determines the possibility of induction of the pathological process. The formation of biofilm is considered as one of the strategies of colonization by bacteria $P$. syringae of plants [10].

It is known from literature that $\mathrm{S}$ - and R-forms of bacteria can vary significantly in the ability to form biofilms on different surfaces [11] and the ability to adhesion as the first stage of biofilm formation [9].

It has been found that spontaneous and induced R-forms of $P$. syringae pv. atrofaciens UKM B-1011 better form biofilm, compared to the S-form of this strain. So, the mass of biofilm of the induced by Alpha Super R-form of $P$. syringae pv. atrofaciens UKM B-1011 was more than 2 times, and the spontaneous Rform of $P$. syringae pv. atrofaciens UKM V-1011 was more than 3 times greater than the weight of the biofilm formed by the S-form of $P$. syringae pv. atrofaciens UKM B -1011 (Table 3).

3. The accumulation of biomass in the planktonic culture and biofilm of $S$ - and R- forms of $P$. syringae pv. atrofaciens UKM B-1011

\begin{tabular}{|l|l|l|}
\hline \multicolumn{1}{|c|}{ Variant of experience } & $\begin{array}{l}\text { The accumulation of biomass } \\
\text { in the planktonic culture, } \mathrm{E}_{540}\end{array}$ & $\begin{array}{l}\text { The accumulation of } \\
\text { biomass in the } \\
\text { biofilm, } \mathrm{E}_{592}\end{array}$ \\
\hline $\begin{array}{l}\text { S-form of } P . \text { syringae pv. atrofaciens UKM } \\
\text { B-1011 }\end{array}$ & $0,65 \pm 0,03$ & $0,32 \pm 0,04$ \\
\hline $\begin{array}{l}\text { Spontaneous R-form of } P \text {. syringae pv. } \\
\text { atrofaciens UKM B-1011 }\end{array}$ & $0,58 \pm 0,02$ & $1,17 \pm 0,19$ \\
\hline $\begin{array}{l}\text { Induced by insecticide R-form of } P . \\
\text { syringae pv. atrofaciens UKM B-1011 }\end{array}$ & $0,55 \pm 0,01$ & $0,75 \pm 0,04$ \\
\hline
\end{tabular}

\section{Conclusions.}

It was found that Alfa Super insecticide is characterized by low toxicity to phytopathogenic bacteria $P$. syringae pv. atrofaciens, which are pathogens of cereals. But its action significantly increases the frequency of morphological dissociation in phytopathogenic bacteria $P$. syringae pv. atrophaciens. $P$. syringae pv. atrofaciens R-forms are characterized by increased ability to form biofilms and grow more actively at a temperature of $40^{\circ} \mathrm{C}$ while retaining virulence. This can lead to the formation of more aggressive populations of this pathogen in nature. 


\section{References}

1. Specifics of pesticides effects on the phytopathogenic bacteria / V. Patyka, N. Buletsa, L. Pasichnyk et al. // Ecol. Chem. Eng. S. - 2016. - Vol.23, N 2. - P. $311-331$.

2. Mil'ko Ye.S. Geterogennost' populyatsii bakteriy i protsess dissotsiatsii / Ye.S. Mil'ko, N.S. Yegorov. - M.: Izd-vo MGU, 1991. - 144 s. Russian.

3. Mil'ko Ye.S. Protsess dissotsiatsii u bakteriy: Uchebnoye posobiye / Ye.S. Mil'ko, I.B. Kotova, A.I. Netrusov. - M.: MAKSS Pres, - 2007. - 68 s. Russian.

4. Natural variability of morphological, biochemical and pathogenic properties of collection cultures of phytopathogenic bacteria N.A. Muras, R.I. Gvozdyak, N.V. Zhitkevich, A.G. Azimtsev // Microbiol. J. 1983. — Vol, 45, N 5. - P.36-42. Ukrainian.

5. Rough and smooth morphotypes isolated from Lactobacillus farciminis CNCM I-3699 are two closely-related variants / R. Tareb, M. Bernardeau, P. Horvath, J.P. Vernoux // Int. J. Food Microbiol. 2015. - Vol. 193, N 16. - P.82 - 90.

6. Perelik pestytsydiv $\mathrm{i}$ ahrokhimikativ, dozvolenykh do vykorystannya $v$ Ukrayini. $-\mathrm{K}$.: Yunivest Media, 2014. - $832 \mathrm{~s}$. Ukrainian.

7. Methods in phytobacteriology IZ. Klement, K. Rudolf, D. Sands et al. — Budapest: Academiai Kiado, 1990. $-568 \mathrm{p}$.

8. The preculiarity of Pseudomonas aeruginosa ATCC 27853 biofilm formation at the dark or photoinduced action of bismuth-containing porphyrins / M.B. Galkin, S.V. Vodsinsky, F.M. Kirichenko, V.O. Ivanytsia //Microbiology and biotechnology. - 2010. - N 3. - P. 51 - 60. Ukrainian.

9. Adhesion and splash dispersal of Salmonella enterica typhimurium on tomato leaflets: effects of rdar morphotype and trichome density / J.M. Cevallos-Cevallos, G. Gu, M.D. Danyluk, A.H. van Bruggen // Int. J. Food Microbiol. - 2012. - Vol. 160, N 1. - P. 58 - 64.

10. Ueda A. Characterization of the ability to form biofilms by plant-associated Pseudomonas species / A. Ueda, H. Saneoka // Curr. Microbiol. - 2015. Vol. 70, N 4. - P. 506 - 513.

11. Greendyke $R$. Differential antibiotic susceptibility of Mycobacterium abscessus variants in biofilms and macrophages compared to that of planktonic bacteria / R. Greendyke, T.F. Byrd // Antimicrob Agents Chemother. - 2008. - Vol. 52, N 6. - P. 2019 -2026. 